\title{
La mirada de Acteón
}

\section{( Carlos Masotta \\ Conicet/UBA}

"iLadrón, ladrón!", grita el ladrón. O peor, “jasesino!”, el asesino. El criminal fue descubierto y, como está en apuros, en su huida juega a la confusión y a las inversiones. En este sentido, la nota editorial "Niñas madres con mayúsculas" que La Nación publicó el $1^{\circ}$ de febrero de 2019, si no fuera ominosa, daría risa. Para el diario, una niña violada es "madraza" y su madre que la defiende, una "abuela abortista". Esta última es genial. Ningún grupo de rock 0 , mejor, de punk en los años 80 hubiera encontrado un nombre mejor.

El patriarcado tiembla, vocifera y se expone en sus patéticas imágenes. La nota de $L a$ Nación fue encabezada con una fotografía. En la imagen se ve a una niña vestida de rojo que con una mano se aferra a un peluche mientras adelanta la otra en primer plano como una señal de istop! En el diario, parece una mera ilustración pero, si un medio suma una foto es porque sabe bien que aquello de "una imagen vale más que mil palabras" es mentira y que entre ellas no compiten sino que más bien, se refuerzan. La magia de este vínculo puede hacer que una misma fotografía sea usada para fines opuestos y la nota editorial del diario, en su perversa cadena violación infantilmaternidad, jugó a esa opción.

La foto en cuestión se presenta como la imagen de una víctima pero en verdad no lo es. Se trata del tipo de producción de estudio creada para ser vendida en un banco de imágenes. Una modelo posa según indicaciones precisas para condensar el significado buscado. Es la mecánica publicitaria: crea íconos que intentan hacerse pasar por documentos. La foto ya había sido utilizada por el mismo medio como ilustración de violaciones infantiles, pero a pesar de esos antecedentes, ahora, en su editorial era presentada como la foto de una niña oponiéndose no a su violación, sino a su aborto.

Históricamente, la manipulación iconográfica del cuerpo femenino no está desconectada de las violencias ejercidas sobre ese mismo cuerpo. Y este parece ser un caso más. Además de su disponibilidad, ¿qué puede encontrarse en esta foto para ser utilizada una y otra vez, incluso con sentidos diversos?

Sumo aquí mi comentario. Entonces, si la foto no retrata a una víctima, ¿qué muestra?

En ella hay dos aspectos estrechamente vinculados que me parecen singulares y que ponen a la mano derecha de la niña como protagonista central. Con esa mano se hacen dos cosas: connotar el punto de vista construido por la imagen y referir al tópico visual. En relación a lo primero, la escena se completa fuera de cuadro con un violador en off 
(digamos) que avanza sobre el cuerpo de la niña. Sin este fantasma invisible, el gesto no podría comprenderse. Se trata de la construcción de una vacancia sobre la que la foto no da tregua y la llena con el mismo espectador colocándolo así en ese comprometido lugar. En resumen, no se muestra a una víctima sino una posición, un punto de vista violador.

La mano que cubre el rostro remite también a una inflexión de la mirada en el centro de la representación visual de la violencia. La referencia a la violación por medio del juego ver-no ver es vieja y tiene antecedentes pictóricos y mitológicos que refuerzan interpretaciones patriarcales o, por lo menos, puntos de vista masculinos en torno a la intervención del cuerpo femenino como objeto de una mirada tabuada que es transgredida.

La relación entre mirada y violación está presente en algunos mitos clásicos y relatos que supo rescatar, con especial dedicación, la pintura del Renacimiento y del Barroco. Las recreaciones del mito de "Diana y Acteón", del relato bíblico "Susana y los viejos" o de las "Toilette de Venus", sin las que ningún pintor de esa época podía considerarse tal, tienen algo de esto. La mujer es sorprendida en su intimidad por la mirada masculina. Las escenas, también comunes, de rapto y cautiverio de mujeres, van en el mismo sentido. La operación de dominio de género es evidente: no existen casos inversos.

En los engranajes de lo público-mediático, lo visual se juega como un campo de la verdad y la justicia. La representación conjunta de víctima y victimario involucra un comentario sobre la condena de este último. Según el relato bíblico, los viejos que avanzaron sobre el cuerpo de Susana fueron condenados a morir apedreados y, como cuenta el mito de Diana, la impertinente mirada de Acteón fue castigada por la diosa transformándolo en un ciervo que sus propios perros desconocieron y devoraron.

En la foto, el corrimiento del violador del campo de visión deja el centro al cuerpo de la niña como objeto de exposición desplazando al primero al invisible espacio de la impunidad. Ninguna de aquellas pinturas había llegado a tanto. Ninguna de esas representaciones que martillaron con la combinación de erotismo y violencia sobre las mujeres, recrearon el punto de vista desde la posición de un violador de niñas. Hubo que esperar al siglo XX y, en especial, al XXI con su voraz mirada de cámara de seguridad, de selfie, de dron y de GoPro para lograr esa imagen. Por supuesto, no es algo exclusivamente tecnológico ni visual. El resto lo hace el conservadurismo sin bozal en auge.

La nota editorial recibió muchas críticas, incluso por grupos de trabajadores del mismo diario. El medio se vio obligado a responder, y con un corto comunicado aclaró "Las notas editoriales de La Nación representan exclusivamente la posición editorial de la empresa...". A confesión de parte...

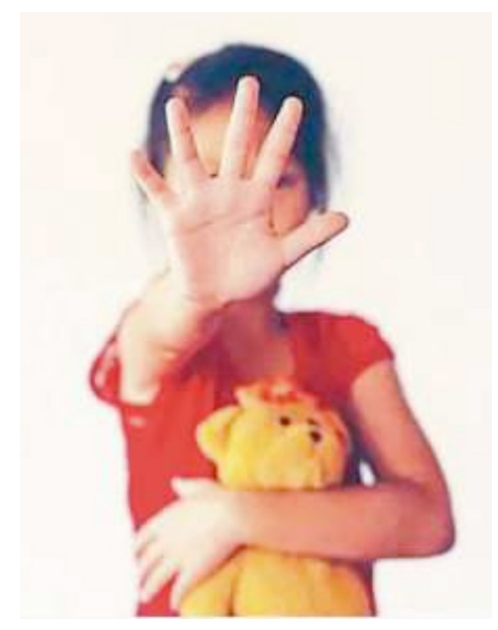

